\title{
Formulasi Pengaturan Intersepsi Dalam Pemberantasan Korupsi Di Era Digital Oleh Kejaksaan Republik Indonesia
}

\author{
Rudi Dwi Prastyono \\ Fakultas Hukum Universitas Islam Indonesia Yogyakarta Indonesia \\ Jln. Cik Di Tiro No. 1, Yogyakarta 55223 Indonesia \\ rudidwiip@gmail.com
}

\begin{abstract}
This study aims to construct legal reform in the disclosure of cases of corruption which tend to be massive and hidden. This study aims to reach the formulation of regulation of corruption case disclosure in the digital era in the form of a strategy to eradicate corruption by using the interception method by the Prosecutor's Office in accordance with the laws and regulations after the Constitutional Court decision Number 5/PUU-VIII/2010. This research uses normative methods through laws and regulations, books and documents. The results of the study conclude, first, that the interception authority in the digital era by prosecutors as investigators, investigators, public prosecutors and executors in eradicating corruption has not received legal legitimacy, so that with the broad authority of the Attorney General's Office and the structure that has been spread throughout Indonesia, it is now necessary supported by the interception authority. Second, the formulation of interception regulation for prosecutors in the future needs to be regulated in a statutory level, and regulated in detail in order to accommodate and limit the authority of law enforcement officials, especially prosecutors in conducting interception.
\end{abstract}

Key Words: Corruption; interception; prosecutor

\begin{abstract}
Abstrak
Penelitian ini bertujuan untuk mengonstruksi pembaruan hukum dalam pengungkapan perkara tindak pidana korupsi yang cenderung masif dan terselubung. Kajian ini hendak menjangkau formulasi pengaturan pengungkapan perkara korupsi di era digital yang berupa strategi pemberantasan tindak pidana korupsi dengan metode intersepsi oleh Kejaksaan sesuai dengan peraturan perundangundangan pasca putusan Mahkamah Konstitusi Nomor 5/PUU-VIII/2010. Penelitian ini menggunakan metode penelitian normatif melalui peraturan perundang-undangan, buku dan dokumen-dokumen. Hasil penelitian menyimpulkan, pertama, kewenangan intersepsi di era digital oleh Jaksa selaku penyelidik, penyidik, penuntut umum hingga eksekutor dalam pemberantasan tindak pidana korupsi belum mendapat legitimasi hukum, sehingga dengan kewenangan Kejaksaan yang luas dan struktur yang sudah tersebar di seluruh wilayah Indonesia saat ini perlu didukung kewenangan intersepsi tersebut. Kedua, formulasi pengaturan intersepsi bagi jaksa di masa mendatang perlu diatur dengan peraturan setingkat undang-undang, serta diatur secara detail sehubungan untuk mengakomodasi dan membatasi wewenang aparat penegak hukum, terutama Jaksa dalam melakukan intersepsi.
\end{abstract}

Kata-kata Kunci: Jaksa; intersepsi; korupsi 


\section{Pendahuluan}

Sebagaimana diketahui bahwa institusi yang dapat melakukan pemberantasan tindak pidana korupsi adalah KPK, Kejaksaan dan Kepolisian. Tindakan yang dapat dilakukan dalam melakukan pemberantasan tindak pidana korupsi oleh masing-masing institusi adalah pencegahan dan penindakan. Pencegahan diperlukan untuk menekan perbuatan korupsi dan menjadi efek jera bagi pelaku lain yang mencoba melakukan perbuatan korupsi.

Abstraknya perbuatan korupsi sehingga sangat sulit jika penindakannnya dilakukan hanya dengan cara yang konvensional. Cara konvensional ini diantaranya melihat data/laporan, melihat/mengukur/menghitung sebuah pekerjaan, mendengar pengakuan "orang dalam/orang tersakiti", atau pengakuan dari pelaku korupsi itu sendiri. Cara-cara konvensional seperti itu tidak akan membuat jera para pelaku korupsi. Penegakan hukum yang modern dengan metode intersepsi dapat menjadi alat efektif dalam membongkar kasus-kasus korupsi yang kerap terselubung, penuh siasat dan berbagai pengakalan kepada aparat penegak hukum. Keberhasilan Komisi Pemberantasan Tindak Pidana Korupsi (KPK) menggunakan teknologi intersepsi ini terbukti dapat membongkar kasus korupsi dengan nilai yang cukup fantastis.

Penjelasan Pasal 31 ayat (1) Undang-Undang Nomor 19 Tahun 2016 tentang Perubahan Atas Undang-Undang Nomor 11 Tahun 2008 tentang Informasi dan Transaksi Elektronik selanjutnya disebut UU ITE menyebut bahwa Intersepsi atau penyadapan adalah kegiatan untuk mendengarkan, merekam, membelokkan, mengubah, menghambat, dan/atau mencatat transmisi Informasi Elektronik dan/atau Dokumen Elektronik yang tidak bersifat publik, baik menggunakan jaringan kabel komunikasi maupunjaringan nirkabel, seperti pancaran elektromagnetis atau radio frekuensi. Meski penyadapan merupakan suatu pelanggaran Hak Asasi Manusia (HAM) karena menjangkau ranah privasi seseorang, namun dapat dibenarkan menurut undangundang dalam rangka penegakan hukum.

Kejaksaan RI dalam pemberantasan korupsi berwenang melakukan penyelidikan, penyidikan dan penuntutan dalam perkara Tindak Pidana Korupsi sebagaimana UU Nomor 16 Tahun 2004 tentang Kejaksaan RI. Kewenangan tersebut sama seperti kewenangan KPK, karena dapat dilakukan berdasarkan Pasal 26 Undang-Undang Nomor 31 Tahun 1999 tentang Pemberantasan Tindak Pidana Korupsi. ${ }^{1}$ Kewenangan tersebut khusus bagi "penyidik" tindak pidana korupsi untuk melakukan penyadapan bukan penyelidik. Penyadapan oleh

1 Penjelasan Pasal 26 Undang-Undang Nomor 31 Tahun 1999 tentang Pemberantasan Tindak Pidana Korupsi, menyebutkan bahwa Kewenangan penyidik dalam pasal ini termasuk wewenang untuk melakukan penyadapan (wiretapping). 
Kejaksaan hanya bisa dilakukan pada tahap penyidikan, namun bukan untuk membuka suatu kasus sebagaimana yang dilakukan oleh KPK pada tahap penyelidikan. UU Nomor 36 Tahun 1999 tentang Telekomunikasi mengatur bahwa Jaksa Agung dalam melakukan penyadapan dapat mengajukan permintaan kepada penyelenggara jasa telekomunikasi (provider) untuk merekam informasi yang dikirimkan atau diterima oleh pengguna jasa telekomunikasi tertentu. Sebagaimana Pasal 42 ayat (2) UU No. 36 Tahun 1999 tentang Telekomunikasi yang berisi:

“Untuk keperluan proses peradilan pidana, penyelenggara jasa telekomunikasi dapat merekam informasi yang dikirim dan/atau diterima oleh penyelenggara jasa telekomunikasi serta dapat memberikan informasi yang diperlukan atas:

a. Permintaan tertulis Jaksa Agung dan atau Kepala Kepolisian Republik Indonesia untuk tindak pidana tertentu;

b. Permintaan penyidik untuk tindak pidana tertentu sesuai dengan undangundang yang berlaku"

Kewenangan Jaksa Penyidik dalam upaya pemberantasan tindak pidana korupsi masih cenderung lemah karena tidak bisa melakukan intersepsi di tahap penyelidikan dan jikalaupun akan melakukan intersepsi di tahap penyidikan, Kejaksaan tidak bisa melakukannya secara mandiri. Padahal, Kejaksaan memiliki 520 kantor yang tersebar di seluruh Indonesia yang tentunya akan sangat efektif dan efisien dari segi waktu dan biaya untuk melakukan intersepsi di tahap penyelidikan tindak pidana korupsi di seluruh wilayah Indonesia.

\section{Rumusan Masalah}

Berdasarkan uraian di atas maka pembahasan penelitian ini akan fokus menjawab permasalhan hukum yaitu: pertama, bagaimana persoalan pengaturan intersepsi oleh Kejaksaan dalam penegakan hukum tindak pidana korupsi di Indonesia? Kedua, bagaimana formulasi pengaturan intersepsi bagi Kejaksaan di masa mendatang?

\section{Tujuan Penelitian}

Tujuan dari penelitian ini adalah untuk mengetahui efektifitas penggunaan intersepsi di era digital oleh jaksa selaku penyelidik, penyidik, penuntut umum hingga eksekutor dengan kewenanganya yang luas dan sudah tersebar di seluruh Indonesia dengan dukungan lawfull interception dari negara, serta untuk 
mendapatkan formulasi terhadap ketentuan mengenai intersepsi bagi Kejaksaan di masa mendatang.

\section{Metode Penelitian}

Metode yang digunakan oleh peneliti adalah metode hukum normatif, yaitu dengan meneliti berbagai sumber bacaan yang relevan dengan tema penelitian, meliputi peraturan perundang-undangan yang bersifat teoritis ilmiah yang dapat menganalisa permasalahan yang diteliti. Fokus kajian menelaah dan mengkaji berkaitan dengan kenggunaan intersepsi oleh Kejaksaan dalam penanganan perkara tindak pidana korupsi di Indonesia.

\section{Hasil Penelitian dan Pembahasan}

Persoalan Pengaturan Intersepsi oleh Kejaksaan dalam Penegakan Hukum Tindak Pidana Korupsi di Indonesia

Penegakan hukum di era digital memiliki ciri khas khusus dalam penanganan perkaranya. Penyidik tindak pidana korupsi wajib dibekali kemampuan mumpuni dalam mengungkap perkara tindak pidana korupsi di era digital. Dalam beberapa kasus pengadaan barang dan jasa walaupun sudah melalui berbagai macam aplikasi digital e-government, e-katalog dan berbagai aplikasi digital lainnya yang dapat dilihat oleh masyarakat guna menunjang transparansi dan akuntabilitas, tetapi tidak menyurutkan perbuatan korupsi di Indonesia. Bahkan perbuatan korupsi yang terselubung semakin marak tetapi tidak dapat di proses karena minimnya alat bukti.

Intersepsi oleh Jaksa saat ini sudah dilakukan namun lebih terfokus pada eksekusi pelaku tindak pidana yang melarikan diri atau buron. Sedangkan dalam proses penyelidikan, jaksa tidak memiliki kewenangan dalam melakukan intersepsi. Alat yang dimiliki pun terbatas serta berdasarkan regulasi haruslah meminta bantuan provider atau pihak lain. Padahal, intersepsi telah menjadi alternatif yang paling efektif dalam investigasi kriminal seiring dengan perkembangan modus kejahatan, termasuk kejahatan korupsi yang marak menggunakan teknologi sebagai media kejahatan. Penyadapan juga dipandang sebagai alat pencegahan dan pendeteksi kejahatan. ${ }^{2}$

Hal tersebut tentunya menjadi penghambat tersendiri dalam penegakan hukum, karena ketika akan melakukan intersepsi sementara harus meminta bantuan provider maka kecepatan dalam melakukan proses intersepsi menjadi lambat. Intersepsi mengingat prinsip "velox et exactus" yang artinya: informasi

2 Supriyadi Widodo Eddyono. "Mengurai Pengaturan Penyadapan dalam Rancangan KUHAP”, Jurnal Teropong, Vol. 1 Agustus 2014, hlm. 23. 
yang disadap haruslah mengandung informasi terkini dan akurat. Intersepsi harus mengandung kepentingan khusus yang dilakukan dengan cepat dan akurat. Dalam kondisi inilah, di dalam penyadapan terdapat kepentingan yang mendesak, namun tetap harus dilaksanakan sesuai dengan ketentuan perundangundangan, sehingga tidak sewenang-wenang melanggar rights of privacy orang lain.

Tata cara lawfull interception melalui bantuan provider saat ini, jaksa bekerja sama dengan memasang server dan sejumlah peralatan. Lalu, nomor handphone yang menjadi target dimasukkan ke alat tersebut yang pada akhirnya terekam. Dalam hal nomor telepon target bisa sepuluh nomor hingga ribuan nomor bahkan tanpa batasan bisa dilakukan intersepsi dalam waktu yang bersamaan pada satu provider. Namun kondisi saat ini, provider hanya memiliki call data recorder (CDR) yang mendata histori penggunaan telepon. Jika hanya melihat histori penggunaan telepon, tentunya yang terlihat hanyalah rekapan telepon keluar dan masuk tanpa mengetahui isinya. Padahal yang dibutuhkan oleh penyidik adalah isi dari percakapannya, bukan menduga-duga isi dari percakapan target. Atas hal tersebut menjadi kendala dan tidak memperkuat pembuktian. Penyidik membutuhkan IP (Internet Protocol) Address data recorder atas penggunaan HP target, seperti mengambil data terkait pembicaraan di telepon, isi pesan dalam Short Message Service (SMS), email atau isi pesan dalam percakapan (chatting) dengan berbagai aplikasi.

Penyadapan yang dilakukan oleh jaksa dengan meminta bantuan provider ini tentu tidak efektif karena menghambat dalam penegakan hukum, tingkat kebocoran yang tinggi dan dapat menggagalkan operasi penindakan tindak pidana korupsi. Diperlukan alat khusus berupa teknologi yang mampu mendeteksi setiap suara target operasi agar proses penyadapan berjalan efektif. Suara manusia dihasilkan dari udara yang dipompa paru-paru dan melewati pita suara hingga membuat pita suara bergetar. Getaran pita suara inilah yang menghasilkan bunyi. Perbedaan suara yang dimiliki setiap orang ini disebabkan oleh perbedaan pita suara. Bentuk, ukuran tebal atau tipis inilah yang membedakan bagaimana suara seseorang bisa terdengar. ${ }^{3}$

Selain alat yang baik, diperlukan penguatan peraturan perundangundangan yang mumpuni. Putusan Mahkamah Konstitusi Nomor 5/PUUVIII/2010 telah membatalkan bunyi undang-undang tersebut bahwa tata cara mengenai penyadapan tidak bisa jika hanya diatur dalam peraturan pemerintah.

3 Diakses dari https://bobo.grid.id/read/08954863/kenapa-suara-manusia-terdengar-berbeda-beda-yukcari-tahu?page $=$ all, pada tanggal 28 Februari 2020, pukul 16:26 wib 
Tetapi, aturan mengenai penyadapan hanya dapat diatur dalam suatu peraturan setingkat undang-undang. Kesimpulan dalam Putusan Mahkamah Konstitusi Nomor 5/PUU-VIII/2010 sebagai berikut:

\begin{abstract}
"Mahkamah memandang perlu untuk mengingatkan kembali bunyi pertimbangan hukum Mahkamah dalam Putusan Nomor 006/PUU-I/2003 tersebut oleh karena penyadapan dan perekaman pembicaraan merupakan pembatasan terhadap hak-hak asasi manusia, di mana pembatasan demikian hanya dapat dilakukan dengan undang-undang, sebagaimana ditentukan oleh Pasal 28J ayat (2) UUD 1945. Undang-undang dimaksud itulah yang selanjutnya harus merumuskan, antara lain, siapa yang berwenang mengeluarkan perintah penyadapan dan perekaman dapat dikeluarkan setelah diperoleh bukti permulaan yang cukup, yang berarti bahwa penyadapan dan perekaman pembicaraan itu untuk menyempurnakan alat bukti, ataukah justru penyadapan dan perekaman pembicaraan itu sudah dapat dilakukan untuk mencari bukti permulaan yang cukup. Sesuai dengan perintah Pasal 28J ayat (2) UUD 1945, semua itu harus diatur dengan undangundang guna menghindari penyalahgunaan wewenang yang melanggar hak asasi."
\end{abstract}

Peraturan mengenai penyadapan hingga saat ini belum juga disahkan oleh badan legislatif. Bahkan dalam Rancangan Undang-Undang tentang Penyadapan yang diharapkan mengakomodasi Pasal 31 ayat (4) Undang-Undang Nomor 11 Tahun 2008 tentang UU ITE yang telah dibatalkan oleh Mahkamah Konstitusi juga tak kunjung disahkan. Padahal perbuatan pelaku tindak pidana korupsi dalam era digital ini menggunakan sarana dan teknologi yang canggih.

Putusan Mahkamah Konstitusi mengenai legalitas penyadapan KPK dituangkan dalam Putusan Mahkamah Konstitusi Nomor 006/PUU-I/2003 dalam pertimbangan hukum sebagai beikut:

“terkait pengujian Undang-Undang Nomor 30 Tahun 2002 tentang Komisi Pemberantasan Tindak Pidana Korupsi terhadap UUD 1945 yang diajukan oleh Komisi Pemeriksa Kekayaan Penyelenggara Negara (KPKPN), dan sejumlah perorangan warga negara Indonesia menyatakan kewenangan penyadapan yang dimiliki Komisi Pemberantasan Korupsi (KPK) sebagaimana diatur dalam Pasal 12 ayat (1) Undang-Undang Nomor 30 Tahun 2002 tentang Komisi Pemberantas Tindak Pidana Korupsi adalah konstitusional. Mahkamah Konstitusi menjelaskan hak privasi bukanlah bagian dari hak-hak yang tidak dapat dikurangi dalam keadaan apapun (nonderogable rights), sehingga negara dapat melakukan pembatasan terhadap pelaksanaan hak-hak tersebut dengan menggunakan Undang-Undang, sebagaimana diatur dalam Pasal 28J ayat (2) Undana-Undang Dasar Negara Republik Indonesia Tahun 1945. Lebih lanjut, Mahkamah Konstitusi menyatakan, "untuk mencegah kemungkinan penyalahgunaan kewenangan untuk penyadapan dan perekaman Mahkamah Konstitusi berpendapat perlu 
ditetapkan perangkat peraturan yang mengatur syarat dan tata cara penyadapan dan perekaman dimaksud."

Penegakan hukum merupakan suatu proses untuk merealisasikan input berupa hukum formal-materil yang didalamnya bekerja seperangkat alat-alat produksi, yang berbahan bakar pokok kepekaan hati nurani, untuk memperoleh luaran berupa produk tindakan, yang mampu memberikan kepuasan bagi banyak orang, menikmati kehidupan harmonis dalam jangka panjang secara seimbang. ${ }^{4}$ Penegakan hukum dalam pemberantasan korupsi diperlukan oleh negara Indonesia mengingat setiap anggaran APBN maupun APBD diperuntukkan untuk kesejahteraan dan kemakmuran rakyat.

Tindak pidana korupsi yang bersifat meluas kepada seluruh masyarakat berdampak sistemik walau tak kasat mata terkena dampak secara langsung/fisik, tetapi perbuatan korupsi dapat berdampak secara meluas atas kesejahteraan rakyat secara keseluruhan. Cara penegakan hukum atas pemberantasan korupsi diperlukan metode-metode yang modern mengingat cara penanggulangan konvensional tidak akan mampu mengungkap korupsi, apalagi korupsi jenis suap.

Sesuai Pasal 28J ayat (2) UUD NRI 1945, pembatasan hak asasi manusia harus diatur dengan undang-undang guna menghindari penyalahgunaan wewenang yang melanggar hak asasi. Setelah jaksa selaku penyidik tindak pidana korupsi sudah memiliki alat yang mumpuni dan sumber daya manusia maka jaksa dapat melakukan kegiatan intersepsi setelah pengaturan dalam undang-undang mengatur jelas dan tanpa disparitas terhadap aparat penegak hukum yang dapat melakukan pemberantasan tindak pidana korupsi.

Kejaksaan Republik Indonesia memiliki bidang intelijen yang tersebar di seluruh Indonesia yang mempunyai tugas fungsi sebagaimana Pasal 30 ayat (3) UU No. 16 Tahun 2004 tentang Kejaksaan yaitu sebagai berikut:

“Dalam bidang ketertiban dan ketentraman umum, kejaksaan turut meyelenggarakan kegiatan:

a. Peningkatan kesadaran hukum masyarakat;

b. Pengamanan kebijakan penegakan hukum;

c. Pengawasan peredaran barang cetakan;

d. Pengawasan kepercayaan yang dapat membahayakan masyarakat dan negara;

e. Pencegahan penyalahgunaan dan/atau penodaan agama;

f. Penelitian dan pengembangan hukum serta statik kriminal."

4 T. Subarsyah Sumadikara, Penegakan Hukum (Sebuah Pendekatan Politik Hukum dan Politik Kriminal), Bandung, Kencana Utama, 2009, hlm. 1. 
Kepentingan intersepsi seharusnya diberikan kepada fungsi Intelijen Kejaksaan sebagai pendukung data kepada bidang tindak pidana khusus dalam penyidikan tindak pidana korupsi. Intelijen Kejaksaan jelas diakui oleh negara sebagai bagian dari Intelijen Negara diatur dalam Undang-Undang Nomor 17 Tahun 2011 tentang Intelijen. Pasal 13 Undang-Undang Nomor 17 Tahun 2011 tentang Intelijen Negara sebagai berikut:

“Pasal 13 UU Nomor 17 Tahun 2011: (1) Intelijen Kejaksaan Republik Indonesia sebagaimana dimaksud dalam Pasal 9 huruf $d$ menyelenggarakan fungsi Intelijen penegakan hukum. (2) Fungsi Intelijen sebagaimana dimaksud pada ayat (1) dilaksanakan sesuai dengan ketentuan peraturan perundang-undangan."

Intelijen kejaksaan menyelenggarakan fungsi Intelijen penegakan hukum. Fungsi penegakan hukum yang dimaksud adalah proses dilakukannya upaya untuk tegaknya atau berfungsinya norma-norma hukum secara nyata sebagai pedoman perilaku dalam lalu lintas atau hubungan-hubungan hukum dalam kehidupan bermasyarakat dan bernegara. Ditinjau dari sudut subyeknya, penegakan hukum itu dapat dilakukan oleh subyek dalam arti luas yaitu sebagai upaya penegakan hukum yang melibatkan semua subyek hukum dalam setiap hubungan hukum. Siapa saja yang menjalankan aturan normatif atau melakukan sesuatu atau tidak melakukan sesuatu dengan mendasarkan diri pada norma aturan hukum yang berlaku, berarti menjalankan atau menegakkan aturan hukum. Penegakkan hukum dalam arti sempit hanya diartikan sebagai upaya aparatur penegakkan hukum tertentu untuk menjamin dan memastikan tegaknya hukum itu, apabila diperlukan, aparatur penegak hukum itu diperkenankan untuk menggunakan daya paksa. ${ }^{5}$

Intersepsi yang dianggap sebagai upaya paksa dapat dilakukan oleh Intelijen Kejaksaan untuk mengumpulkan alat bukti. Namun hal tersebut harus tegas diatur dalam undang-undang. Perkuatan bidang Intelijen semata-mata untuk menunjang keberhasilan bidang tindak pidana khusus dalam melakukan penegakan hukum tindak pidana korupsi. Sehingga informasi intelijen kejaksaan bisa dijadikan bukti permulaan yang cukup dan digunakan untuk menangkap pelaku korupsi dan ditindaklanjuti oleh bidang tindak pidana khusus pada kejaksaan.

Tugas dan fungsi Intelijen Kejaksaan telah diatur dalam peraturan internal Kejaksaan. Tugas dan kewenangan Intelijen Kejaksaan ini pada dasarnya mendukung penegakan hukum baik preventif dan represif. Berdasarkan Peraturan Presiden Republik Indonesia Nomor 38 Tahun 20010 dan Peraturan 
Jaksa Agung Republik Indonesia Nomor: PER-009/A/JA/01/2011 tanggal 24 Januari 2011 tentang Organisasi dan Tata Kerja Kejaksaan Republik Indonesia disebutkan Tugas pokok dan fungsi intelijen Kejaksaan berdasarkan Pasal 622 adalah unsur pembantu pimpinan mempunyai tugas dan wewenang:

1. Melakukan kegiatan intelijen penyelidikan, pengamanan dan penggalangan untuk melakukan pencegahan tindak pidana guna mendukung penegakan hukum baik preventif maupun represif di bidang ideologi, politik, ekonomi, keuangan, sosial budaya, pertahanan dan keamanan, melaksanakan cegah tangkal terhadap orang-orang tertentu dan/atau turut menyelenggarakan ketertiban dan ketentraman umum dan penanggulangan tindak pidana serta perdata dan tata usaha negara di daerah hukumnya;

2. Memberikan dukungan intelijen Kejaksaan bagi keberhasilan tugas dan kewenangan Kejaksaan, melakukan kerjasama dan koordinasi serta pemantapan kesadaran hukum masyarakat di daerah hukumnya.

Pengaturan tugas dan fungsi Intelijen Kejaksaan perlu dikuatkan dalam aturan setingkat undang-undang guna kepastian hukum dan tidak melanggar Hak Asasi Manusia. Peraturan mengenai intersepsi yang dapat dilakukan oleh jaksa, yang ditugaskan dalam bidang Intelijen sejalan dengan peraturan perundang-undangan yang sudah ada. Sebagaimana Badan Intelijen Negara (BIN) dapat melakukan penyadapan terhadap perkara tindak pidana terorisme sebagai pendukung data kepada BNPT atau Kepolisian dalam menindaklanjuti perkara terorisme. Seharusnya Intelijen Kejaksaan dapat juga melakukan intersepsi terhadap segala indikasi perbuatan melanggar hukum sebagai bagian dari upaya preventif dan pendukung data dalam rangka melaksanakan tugas dan wewenang penegakan hukum.

\section{Formulasi Ketentuan Intersepsi di Masa Mendatang}

Konsep negara hukum, baik konsep rule of law maupun konsep rechtsstaat menempatkan pengakuan dan perlindungan terhadap hak-hak asasi manusia sebagai prinsip fundamentalnya. Konsep the rule of law mengedepankan prinsip equality before the law dan konsep rechsstaat mengedepankan prinsip wetmatigheid kemudian menjadi rechtmatigheid dalam rangka melindungi hak asasi manusia. ${ }^{6}$

Intersepsi atau penyadapan merupakan salah satu kegiatan untuk mencuri informasi elektronik (biasanya suara) dengan atau tanpa memasang alat atau perangkat tambahan pada jaringan telekomunikasi untuk mendapatkan informasi

\footnotetext{
${ }^{6}$ Philipus M. Hadjon, Perlindungan Hukum bagi Rakyat di Indonesia, Peradaban, Surabaya, 2007, hlm. 79-80.
} 
baik secara diam-diam ataupun terang-terangan. Perdebatan penggunaan metode penyadapan bukan hal baru dikalangan pegiat hukum di Indonesia. Meski demikian, saat ini intersepsi telah memberikan warna baru dalam proses penyelidikan dan penyidikan sampai tahap pembuktian. ${ }^{7}$

Berdasarkan putusan Mahkamah Konstitusi Nomor 5/PUU-VIII/2010 yang mempersyaratkan bahwa dalam konteks landasan hukum, intersepsi harus diatur setingkat undang-undang. Pelanggaran terhadap hak asasi manusia menjadi salah satu hal yang menjadi pertimbangan krusial dalam menentukan bahwa intersepsi dapat dilakukan tetapi harus diatur dengan undang-undang.

Hak Asasi Manusia sangat fundamental dalam penentuan kewenangan penyadapan. Pasal 12 Universal Declaration of Human Rights menyatakan bahwa:

Article 12:

"No one shall be subjected to arbitrary interference with his privacy, family, home or correspondence, nor to attacks upon his honour and reputation. Everyone has the right to the protection of the law against such interference or attacks."

Tidak seorang pun akan mengalami gangguan sewenang-wenang dengan privasi, keluarga, rumah atau korespondensi, atau untuk menyerang kehormatan dan reputasinya. Setiap orang punya hak atas perlindungan hukum terhadap gangguan atau serangan semacam itu. Pasal 17 Undang-Undang Nomor 12 Tahun 2005 tentang Pengesahan International Covenant on Civil and Political Rights (Kovenan Internasional Tentang Hak-Hak Sipil dan Politik) juga menentukan bahwa: "tidak boleh dicampurinya secara sewenang-wenang atau secara tidak sah privasi, keluarga, rumah atau surat menyurat seseorang"

Melacak percakapan menggunakan teknologi dalam intersepsi dapat menjadi suatu pelanggaran, namun dalam rangka penegakan hukum atas perintah hakim atau atas suatu kekuasaan tertentu, maka hal tersebut dapat dibenarkan demi terciptanya kondisi keamanan, ketertiban di masyarakat. Sebagaimana bunyi Pasal 32 Undang-Undang Nomor 39 Tahun 1999 tentang Hak Asasi Manusia yang isinya yaitu:

"Kemerdekaan dan rahasia dalam hubungan surat-menyurat termasuk hubungan komunikasi melalui sarana elektronik tidak boleh diganggu, kecuali atas perintah hakim atau kekuasaan lain yang sah sesuai dengan ketentuan peraturan perundang-undangan."

Berdasarkan aturan tersebut, dikarenakan Indonesia yang telah meratifikasi Kovenan Internasional Hak Sipil dan Politik melalui Undang-Undang Nomor 12 Tahun 2005, maka ketentuan Pasal 17 Kovenan tersebut juga telah menjadi bagian

${ }^{7}$ Edmon Makarim, Komplikasi Hukum Telematika, PT. Raja Grafindo Persada, Jakarta, 2004, hlm. 231 
dari sistem hukum hak asasi manusia nasional. Ratifikasi undang-undang tersebut juga memandatkan bahwa pengecualian dapat dilakukan sepanjang adanya suatu peraturan yang mengaturnya setingkat undang-undang.

Hak privasi bukanlah bagian dari hak-hak yang tidak dapat dikurangi dalam keadaan apapun (non-derogable rights), sehingga negara dapat melakukan pembatasan terhadap pelaksanaan hak-hak tersebut dengan menggunakan undang-undang. Sebagaimana diatur dalam Pasal 28J ayat (2) UUD NRI 1945, sehingga setiap kegiatan intersepsi harus diatur dengan undang-undang bukan dalam peraturan di bawah undang-undang. Formulasi pengaturan mengenai intersepsi yang diatur dalam undang-undang harus mengatur berbagai macam hal diantaranya yaitu:

1. Lembaga/Instansi mana saja yang berhak melakukan intersepsi berdasarkan surat perintah;

2. Tata cara pelaksanaan intersepsi;

3. Dasar dilakukannya intersepsi;

4. Jangka waktu dilakukannya intersepsi;

5. Pengelolaan Hasil data dari intersepsi;

6. Pengawasan terhadap pelaksanaan intersepsi.

Mahkamah Konstitusi, khususnya dalam soal penyadapan, dalam 3 putusannya telah menyatakan secara tegas mengenai pembatasan terkait intersepsi. Bahwa untuk mencegah kemungkinan penyalahgunaan kewenangan untuk penyadapan dan perekaman Mahkamah Konstitusi berpendapat perlu ditetapkan perangkat peraturan yang mengatur syarat dan tata cara penyadapan dan perekaman dimaksud. 8

Sehingga formulasi terhadap ketentuan intersepsi memang harus dirumuskan secara yuridis dalam peraturan setingkat undang-undang. Undangundang yang mengatur kegiatan intersepsi harus detail mengatur terkait hal-hal fundamental dalam pengaturan intersepsi. Khusus jaksa harus secara tertulis atas batasan-batasan maupun kewenangan-kewenangan yang melekat pada aparat penegak hukum tersebut dalam melakukan kegiatan intersepsi. Dengan demikian, apabila intersepsi dilakukan oleh aparat negara dan kewenangan tersebut secara jelas di berikan oleh undang-undang dan untuk kepentingan penegakan hukum, maka tindakan tersebut tidak melanggar hak asasi manusia. ${ }^{9}$

\footnotetext{
8 Putusan Mahkamah Konstitusi Nomor Perkara: 006/PUU-I/2003

9 Kristian dan Yopi Gunawan, Sekelumit Tentang Hukum Penyadapan dalam Hukum Positif di Indonesia, Nuansa Aulia, Bandung, 2013, hlm. 105
} 
Isi pasal yang dengan tegas menyatakan penyadapan dapat dilakukan pada tahap penyelidikan, menjadikan jelas tolak ukur sejak kapan dapat dilakukan penyelidikan. Waktu yang terbatas dapat dilakukan oleh penyelidik untuk melakukan penyadapan. Hal tersebut berfungsi untuk menemukan peristiwa pidana yang sulit ditemukan jika tanpa bantuan intersepsi. Sehingga upaya paksa penyadapan dapat dilakukan secara lawfull interception jika uraian unsur diatur dengan tegas baik dalam RUU KUHAP maupun dalam RUU Penyadapan.

Sehingga hukum yang dicita-citakan dalam draft RUU Penyadapan seharusnya terdapat pasal yang khusus mengenai penyadapan oleh aparat penegak hukum yaitu:

"Pelaksanaan penyadapan dalam rangka penegakan hukum, dilakukan pada tahap penyelidikan dan penyidikan yang dapat dilakukan oleh intelijen penegakan hukum."

\section{Penutup}

Artikel ini menyimpulkan, pertama, pada dasarnya kejaksaan tidak berwenang melakukan intersepsi. Jaksa tidak dapat melakukan penyadapan pada tahap penyelidikan perkara tindak pidana korupsi, karena pada tahap penyidikan dan penuntutan atas lawfull interception jaksa harus melalui bantuan provider. Kegiatan penyadapan yang dilakukan oleh jaksa dengan harus meminta bantuan provider tentu tidak efektif, menghambat penegakan hukum, tingkat kebocoran yang tinggi dan dapat menggagalkan operasi penindakan tindak pidana korupsi pada tahap penyidikan. Intersepsi oleh jaksa dilakukan pada tahap eksekusi guna menangkap pelaku tindak pidana yang telah divonis pengadilan dan telah memiliki kekuatan hukum tetap atau inkracht tetapi melarikan diri atau buron, baik dalam perkara tindak pidana korupsi maupun perkara tindak pidana umum. Pengaplikasian intersepsi oleh jaksa dalam pemberantasan tindak pidana korupsi haruslah dilakukan langsung oleh internal kejaksaan dengan bantuan alat penunjang intersepsi dan SDM yang memadai yang dapat menjangkau seluruh daerah di Indonesia.

Kedua, formulasi pengaturan intersepsi di masa mendatang bagi Kejaksaan, berdasarkan putusan Mahkamah Konstitusi Nomor 5/PUU-VIII/2010 yang mensyaratkan bahwa landasan hukum intersepsi harus setingkat undangundang. Prinsip legalitas dalam melakukan tindakan intersepsi adalah tindakan apapun yang dilakukan oleh pemerintah melalui aparat penegak hukum harus melalui jalur hukum. Perundang-undangan tersebut dapat dituangkan dan disahkan dalam perubahan Rancangan Undang-Undang KUHAP, Rancangan Undang-Undang Penyadapan atau Rancangan Undang-Undang Kejaksaan 
dengan menegaskan unsur kewenangan jaksa dalam melakukan intersepsi yaitu: "Pelaksanaan penyadapan dalam rangka penegakan hukum, dilakukan pada tahap penyelidikan dan penyidikan yang dapat dilakukan oleh intelijen penegakan hukum."

Artikel ini menyarankan agar penanganan perkara tindak pidana korupsi lebih optimal maka Kejaksaan harus diberi kewenangan intersepsi dalam semua tingkatan proses penanganan perkara yaitu sejak penyelidikan, penyidikan dan penuntutan bahkan hingga tahap eksekusi. Intersepsi pelaku tindak pidana korupsi yang sudah inkracht dan melarikan diri untuk tetap dilakukan intersepsi guna melacak kegiatan dan keberadaannya yang nantinya dapat di eksekusi. Diperlukan sarana sendiri baik alat penunjang maupun SDM yang ahli intersepsi, yang dapat membantu Jaksa dalam mengumpulkan alat bukti pada tahap penyidikan yang dihadirkan pada akhirnya pada tahap penuntutan di persidangan.

Pengaturan intersepsi setingkat undang-undang dapat dituangkan dalam pengesahan Undang-Undang tentang Penyadapan, revisi KUHAP maupun revisi Undang-Undang Kejaksaan yang mengatur mengenai kewenangan penyadapan oleh Jaksa dalam setiap tingkat penanganan perkara. Sarana atau alat penunjang khusus yang canggih sesuai dengan perkembangan di era digital, ahli teknologi informatika atau ahli yang membidangi masalah intersepsi dengan integritas yang tinggi. SDM dapat ditempatkan pada intelijen kejaksaan. Penyadapan tindak pidana korupsi yang dilakukan oleh Jaksa, dilakukan oleh Kejaksaan sendiri berdasarkan peraturan perundang-undangan yang secara teknis dituangkan dalam Peraturan Jaksa Agung (PERJA) atau Standar Operational Procedure (SOP), tanpa melalui pihak ketiga atau provider dan tidak melalui izin pengadilan. Namun, tetap dilakukan audit intersepsi oleh internal Kejaksaan yaitu bidang pengawasan dan eksternal yaitu dari Kominfo atau Komisi Kejaksaan.

\section{Daftar Pustaka}

\section{Buku}

Subarsyah Sumadikara, T., Penegakan Hukum (sebuah pendekatan Politik hukum dan Politik Kriminal), Bandung, Kencana Utama, 2010.

Kristian dan Yopi Gunawan, Sekelumit Tentang Hukum Penyadapan dalam Hukum Positif di Indonesia, Nuansa Aulia, Bandung, 2013.

M. Hadjon, Philipus, Perlindungan Hukum bagi Rakyat di Indonesia, Peradaban, Surabaya, 2007.

Makarim, Edmon, Komplikasi Hukum Telematika, PT. Raja Grafindo Persada, Jakarta, 2004. 


\section{Jurnal}

Supriyadi Widodo Eddyono. "Mengurai Pengaturan Penyadapan dalam Rancangan KUHAP", Jurnal Teropong, Vol. 1 Agustus 2014.

\section{Internet}

https:/ / bobo.grid.id/read/08954863/kenapa-suara-manusia-terdengar-berbedabeda-yuk-cari-tahu?page=all, pada tanggal 28 Februari 2020, pukul 16:26 wib

\section{Peraturan Perundang-undangan}

Undang-Undang Nomor 8 Tahun 1981 tentang Hukum Acara Pidana.

Undang-Undang RI Nomor 30 Tahun 2002 tentang Komisi Pemberantasan Tindak Pidana Korupsi.

Undang-Undang RI Nomor 16 Tahun 2004 tentang Kejaksaan RI.

Undang-Undang RI Nomor 36 Tahun 1999 tentang Telekomunikasi.

Peraturan Jaksa Agung RI Nomor: PERJA-039/A/JA/10/2010 tentang Tata Kelola Administrasi dan Teknis Penanganan Perkara Tindak Pidana Khusus.

Rancangan Undang-undang Penyadapan

Rancangan Undang-undang KUHAP 